\title{
Lipopolysaccharide Induces Prostaglandin H Synthase-2 Protein and mRNA in Human Alveolar Macrophages and Blood Monocytes
}

\author{
Stephen L. Hempel, Martha M. Monick, and Gary W. Hunninghake \\ Department of Veterans Affairs Medical Center and The University of Iowa College \\ of Medicine, Department of Medicine, Iowa City, Iowa 52242
}

\begin{abstract}
We and others have previously demonstrated that human alveolar macrophages produce more $\mathrm{PGE}_{2}$ in response to lipopolysaccharide (LPS) than do blood monocytes. We hypothesized that this observation was due to a greater increase in prostaglandin H synthase-2 (PGHS-2) enzyme mass in the macrophage compared to the monocyte. To evaluate this hypothesis, alveolar macrophages and blood monocytes were obtained from healthy nonsmoking volunteers. The cells were cultured in the presence of 0 to $10 \mu \mathrm{g} / \mathrm{ml}$ LPS. LPS induced the synthesis of large amounts of a new 75-kD protein in human alveolar macrophages, and a lesser amount in monocytes. Synthesis of this protein required more than $6 \mathrm{~h}$ and peaked in 24 to $48 \mathrm{~h}$; the protein reacted with an anti-PGHS-2 antibody prepared against mouse PGHS-2. Associated with synthesis of the protein was a marked increase in LPS-stimulated and arachidonic acid-stimulated synthesis of $\mathrm{PGE}_{2}$ by alveolar macrophages compared to monocytes. Cells not exposed to LPS contained only PGHS-1 and synthesized very little PGE $_{2}$ during culture or in response to exogenous arachidonic acid. An LPSinduced mRNA, which hybridized to a human cDNA probe for PGHS-2 mRNA, was produced in parallel with production of this new protein and was produced in much greater amounts by alveolar macrophages compared to blood monocytes. This mRNA was not detectable in cells not exposed to LPS. In contrast, both types of cells contain mRNA, which hybridizes to a cDNA probe for PGHS-1. This mRNA did not increase in response to LPS. LPS also had no effect on PGHS-1 protein. These data demonstrate that $\mathrm{PGE}_{2}$ synthesis in human alveolar macrophages and blood monocytes correlates to the mass of PGHS-2 in the cell. We conclude that the greater ability of the macrophage to synthesize $\mathrm{PGE}_{2}$ in response to LPS is due to greater synthesis of PGHS-2 by the macrophage. (J. Clin. Invest. 1994. 93:391-396.) Key words: prostaglandin synthase • prostaglandins $\mathbf{E}$
\end{abstract}

\section{Introduction}

The alveolar macrophage is the predominant immune and inflammatory effector cell of the human lung. Although it can initiate inflammation, it also has the capacity to suppress in-

Address correspondence to Dr. Stephen L. Hempel, Department of Medicine, University of Iowa College of Medicine, Iowa City, IA 52242.

Received for publication 2 April 1993 and in revised form 17 June 1993.

J. Clin. Invest.

(c) The American Society for Clinical Investigation, Inc.

0021-9738/94/01/0391/06 \$2.00

Volume 93, January 1994, 391-396 flammation. In response to the inflammatory mediator lipopolysaccharide (LPS), the macrophage will generate large amounts of the anti-inflammatory prostaglandin, prostaglandin $E_{2}\left(P E_{2}\right)(1,2)$. We previously demonstrated that LPS stimulates the macrophage to produce increased amounts of prostaglandin $\mathrm{H}$ synthase (PGHS) ${ }^{1}(3)$. This increase in PGHS mass is believed to markedly increase the capacity of the macrophage to generate $\mathrm{PGE}_{2}(3)$.

It is now evident that in many cell lines there exist two forms of PGH synthase: a constitutive enzyme, designated PGHS-1; and an inducible enzyme, PGHS-2, which has a unique message $(4,5,6,7)$, a unique amino acid sequence $(7$, 8 ), and a unique activity profile ( 9 ). We wished to determine if the LPS-stimulated increase in human macrophage PGHS and $\mathrm{PGE}_{2}$ formation was due to synthesis of PGHS-2 as suggested by recent studies in rat alveolar macrophages $(10)$, or due to synthesis of PGHS-1 as suggested by studies on rat peritoneal and alveolar macrophages (11). In addition, we wanted to explore whether the increased ability of the alveolar macrophage, compared to the peripheral blood monocyte, to synthesize $\mathrm{PGE}_{2}$ following LPS exposure was due to increased synthesis of PGHS-2 by the alveolar macrophage (12).

\section{Methods}

Isolation of alveolar macrophages. The study was approved by the Committee for Investigations Involving Human Subjects at The University of Iowa. To obtain human alveolar macrophages, normal volunteers with a lifetime nonsmoking history, who had no acute or chronic medical illness and were on no medications, underwent bronchoalveolar lavage, as previously described (13). The lavage procedure used five $25-\mathrm{ml}$ aliquots of sterile, warmed saline in each of three segments of the lung.

The lavage fluid was filtered through two layers of gauze and centrifuged at 1,500 rpm for $5 \mathrm{~min}$. The cell pellet was washed twice in HBSS without $\mathrm{Ca}^{2+}$ or $\mathrm{Mg}^{2+}$ and was suspended in culture medium as described below. Cell counts were determined by an electronic counter (Coulter Electronics, Hialeah, FL). Cell differentials were generated by Wright-Giemsa-stained cytocentrifuge preparations.

Isolation of blood monocytes. $225 \mathrm{ml}$ of heparinized blood were obtained by venipuncture following bronchoscopy. Mononuclear cells were isolated using a Ficoll-Hypaque gradient (14). Monocytes were isolated from the mononuclear fraction by washing off the non-adherent cells after incubation for $1 \mathrm{~h}$ at $37^{\circ} \mathrm{C}$. Cell counts and differentials were performed as above.

Cell culture. The macrophages and monocytes were cultured at a density of $1 \times 10^{6}$ cells $/ \mathrm{ml}$ in Rosewell Park Memorial Institute tissue culture medium (RPMI 1640) containing $0.3 \mathrm{mg} / \mathrm{ml} \mathrm{L}$-glutamine, 80 $\mu \mathrm{g} / \mathrm{ml}$ gentamicin, and $5 \%$ endotoxin-free FCS (Hyclone Laboratories, Logan, UT). 6-well flat polystyrene culture dishes (Costar, Cambridge, MA), containing $4 \mathrm{ml}$ of suspended cells in each well, were incubated in an atmosphere of $95 \%$ humidified air $-5 \% \mathrm{CO}_{2}$ at $37^{\circ} \mathrm{C}$.

1. Abbreviation used in this paper: PGHS, prostaglandin $\mathrm{H}$ synthase. 
Control and lipopolysaccharide (LPS; Escherichia coli 026:B6, Sigma Chemical Co., St. Louis, MO) cultures were set up as described in the text and figure legends. At the end of LPS exposure the cell supernatants were removed. The supernatants and the cells were stored frozen at $-70^{\circ} \mathrm{C}$. Viability of the cultured cells was determined using trypan blue exclusion.

Antibody preparation. An in-house polyclonal rabbit anti-PGHS antibody prepared against purified ram seminal vesicle PGHS was used where described in the text (3). Preliminary studies demonstrated that this antibody will detect $\leq 250 \mathrm{ng}$ PGHS-1, purified from ram seminal vesicles, and $\leq 250 \mathrm{ng}$ chicken-recombinant PGHS-2 (nos. PG01 and PG04; Oxford Biomedical Research, Inc, Oxford, MI).

The anti-PGHS-2 was a polyclonal rabbit anti-mouse antibody (no. PG26, Oxford Biomedical Research, Inc.) that was found to be highly specific. The antibody does not cross-react with PGHS-1 nor does it cross-react with a panel of molecular weight marker proteins, and it has no apparent cross-reactivity against other human cell proteins.

Immunoblot detection of PGHS-1 and PGHS-2. Cell pellets from alveolar macrophages and blood monocytes were lysed in $150 \mu \mathrm{l}$ of solubilization buffer at $25^{\circ} \mathrm{C}(1 \%$ Tween $20,10 \mathrm{mM}$ phenylmethylsulfonyl fluoride, $10 \mu \mathrm{g} / \mathrm{ml}$ leupeptin, $171 \mu \mathrm{g} / \mathrm{ml}$ diethyldithiocarbamic acid, $200 \mu \mathrm{g} / \mathrm{ml} \alpha 2$-macroglobulin, and $50 \mathrm{mM}$ Tris, $\mathrm{pH} \mathrm{8}$, all from Boehringer Mannheim Biochemicals, Indianapolis, IN). The cell material was sonicated for $15 \mathrm{~s}$ and then centrifuged at $15,000 \mathrm{~g}$. An aliquot of the supernatant was used to determine protein by the Coomassie blue method (15). Supernatants were then mixed 1:1 with sample buffer ( $20 \%$ glycerol, $4 \%$ SDS, $10 \% \beta$-mercaptoethanol, $0.05 \%$ bromophenol blue, and 1.25 M Tris, ph 6.8). Equal amounts of protein (50$100 \mu \mathrm{g}$ ) were then loaded onto a Bio-Rad Mini-electrophoresis polyacrylamide gel system (Bio-Rad Laboratories, Richmond, CA) using a $4 \%$ stack and a $10 \%$ running gel, and then run at $80 \mathrm{v}$ for $3 \mathrm{~h}$. Cell proteins were transfered to nitrocellulose overnight at $30 \mathrm{v}$. The nitrocellulose was then blocked with $5 \%$ skim milk, washed, and then incubated with antibody for $1 \mathrm{~h}$ at $25^{\circ} \mathrm{C}$. The polyclonal in-house antiPGHS antibody was diluted 1:5,000 and the commercial anti-PGHS-2 antibody was diluted 1:200. The Amersham ECL system was used to detect the antibodies. Kodak X-omat AR film with cassette closure times of 10 to $60 \mathrm{~s}$ resulted in adequate exposure to visualize the bands.

Northern blot analysis. RNA was isolated from the cells by the guanidine isothiocyanate- $\mathrm{CsCl}$ gradient procedure (16). The isolated RNA was fractionated in a $1.5 \%$ denaturing agarose gel containing 2.2 $\mathrm{M}$ formaldehyde (17). E. coli $23 \mathrm{~S}(3.3 \mathrm{~kb})$ and $16 \mathrm{~S}(1.7 \mathrm{~kb})$ rRNAs were included as molecular size standards. RNA loading was confirmed by equivalent ethidium bromide staining in each lane. The RNAs were then transferred to GeneScreen Plus paper as suggested by the manufacturer. PGHS- 1 and PGHS-2 cDNA probes (Oxford Biomedical Research, Inc.) were ${ }^{32} \mathrm{P}$-labeled by nick translation, then hybridized to the blots at $42^{\circ} \mathrm{C}$. Autoradiograms were prepared using exposure times of $18 \mathrm{~h}$.

$P G E_{2}$ determination. $\mathrm{PGE}_{2}$ was measured using a commercial ELISA kit (Oxford Biomedical Research, Inc.).

Statistics. All results shown were confirmed in at least two additional experiments. Linear data were analyzed by one- or two-way ANOVA. Categorical data were analyzed by unpaired $t$ statistics. The specific tests used and the results are depicted in the figure legends.

\section{Results}

Preliminary studies comparing human alveolar macrophages to peripheral blood monocytes suggested that LPS caused an increase in the molecular weight of PGHS in the macrophage. To clarify this observation, a large gel electrophoresis of cell proteins from monocytes and macrophages was performed, and then followed by Western blotting using a polyclonal antibody which detects both PGHS-1 and PGHS-2 (3). Fig. 1 demonstrates that following LPS two proteins are detected, one of
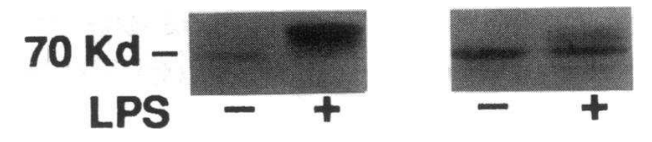

\section{Macrophages Monocytes}

Figure 1. Effect of LPS on PGHS enzyme mass in macrophages and monocytes. Macrophages and monocytes from the same subject were cultured $24 \mathrm{~h}$ in the absence (-) or presence (+) of $10 \mu \mathrm{g} / \mathrm{ml} \mathrm{LPS}$. $100 \mu \mathrm{g}$ of cell protein was loaded onto a $14-\mathrm{cm}$ SDS $7.5 \%$ polyacrylamide slab gel. Immunoblots were then performed with the in-house polyclonal antibody that detects both PGHS-1 and PGHS-2.

$\sim 70 \mathrm{kD}$, which does not increase with LPS stimulation, and a second protein of $\sim 75 \mathrm{kD}$, which is not present in the control cells. This new protein becomes the predominant protein detected in the alveolar macrophage following LPS, and is present in lesser amounts in the LPS-exposed monocytes.

To explore this finding further, macrophages and monocytes were exposed to $10 \mu \mathrm{g} / \mathrm{ml}$ LPS for periods of 6 to $48 \mathrm{~h}$. LPS caused a time-dependent increase in the $75-\mathrm{kD}$ protein in both monocytes and macrophages that was maximum at 24$48 \mathrm{~h}$. An immunoblot from the macrophages is shown in Fig. 2 $A$. There was also a time-dependent increase of $\mathrm{PGE}_{2}$ formation from the LPS-exposed cells that paralleled the increase in the $75-\mathrm{kD}$ protein as shown in Fig. $2 \mathrm{~B}$. These results demonstrate that LPS increases prostaglandin synthesis and increases

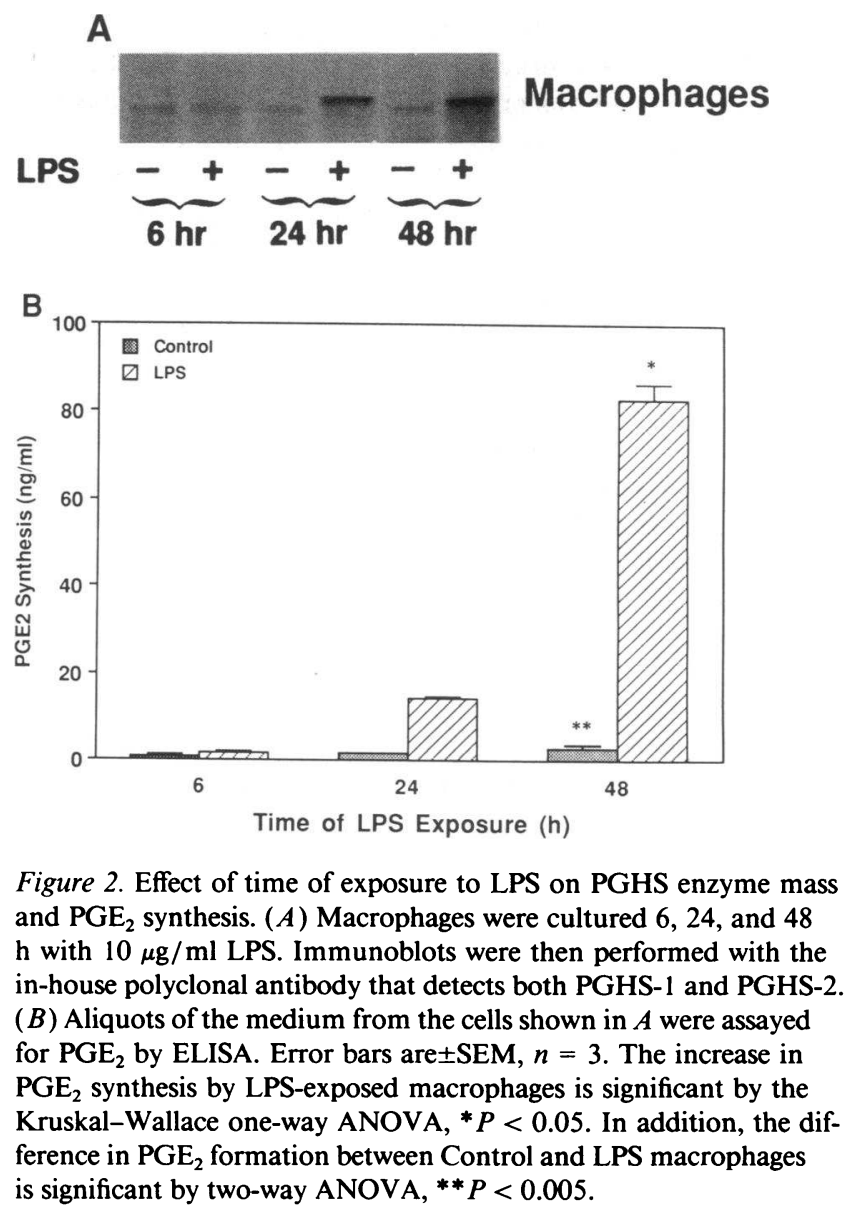


the amount of a $75-\mathrm{kD}$ protein in cultured monocytes and macrophages, consistent with previous observations (3).

Fig. 3 depicts the increase in amount of the $75-\mathrm{kD}$ protein in cultured monocytes and macrophages in response to LPS concentrations of 0.1 to $10 \mu \mathrm{g} / \mathrm{ml}$ for $24 \mathrm{~h}(A)$. The results shown demonstrate that the macrophage responds to lower concentrations of LPS than the monocyte. $\mathrm{PGE}_{2}$ synthesis increases concurrent with the increase in the $75-\mathrm{kD}$ protein as shown in Fig. $3 B$. These observations indicate that there is a LPS concentration-dependent increase in the $75-\mathrm{kD}$ protein mass in monocytes and macrophages that is associated with increased $\mathrm{PGE}_{2}$ formation.

These findings raised the question whether the higher molecular weight LPS-inducible protein was the recently described mitogen-inducible PGHS-2. To address this, LPS-exposed macrophages and monocytes were lysed and cell proteins were evaluated by Western analysis with a specific anti-PGHS-2 antibody. The immunoblot shown in Fig. 4 demonstrates that only the new $75-\mathrm{kD}$ band is detected by the specific antibody. The blot also shows that cells exposed to $3 \mathrm{~h}$ of LPS do not yet express this protein (3). The immunoblot in Fig. 5 compares the anti-PGHS- 2 antibody ( antibody $B$ ) to the

A
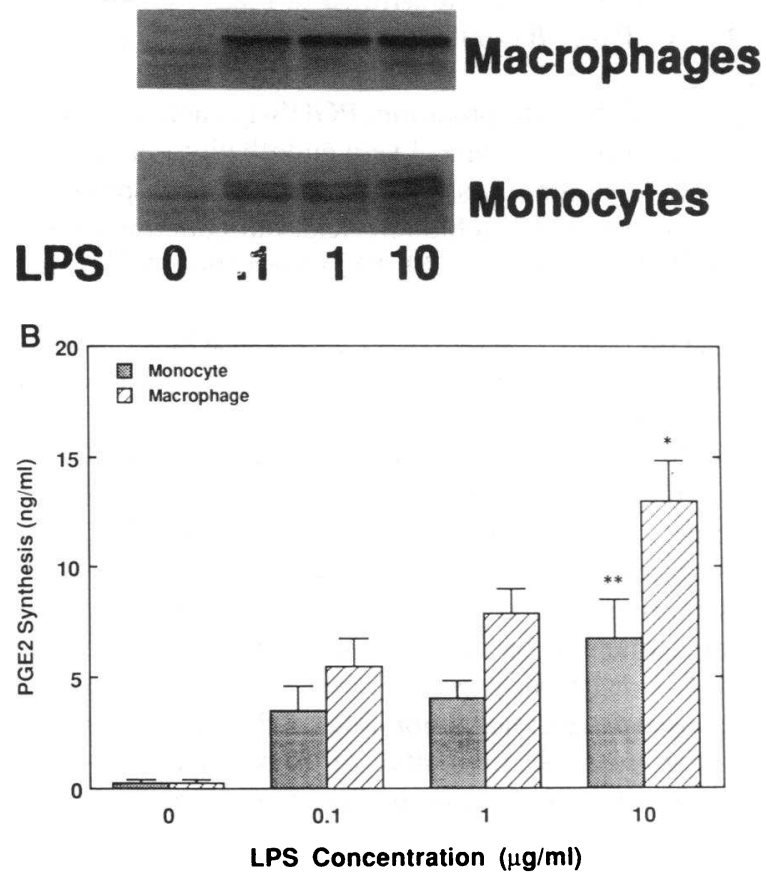

Figure 3. Effect of concentration of LPS on PGHS enzyme mass and $\mathrm{PGE}_{2}$ synthesis. $(A)$ Monocytes and macrophages were cultured 24 $\mathrm{h}$ with 0 to $10 \mu \mathrm{g} / \mathrm{ml}$ LPS. Immunoblots were then performed with the in-house polyclonal antibody that detects both PGHS-1 and PGHS-2. Computerized image analysis of the higher molecular mass band $(75 \mathrm{kD})$ revealed an integrated optical density of $0,950,1,424$, and 1,537 for the macrophage protein and 50,168,263, and 726 for the monocyte protein after LPS concentrations of $0,0.1,1$, and 10 $\mu \mathrm{g} / \mathrm{ml}$ respectively. $(B)$ Aliquots of the medium from the cells shown in $A$ were assayed for $\mathrm{PGE}_{2}$ by ELISA. Error bars are \pm SEM. Results are from three different subjects. The increase in $\mathrm{PGE}_{2}$ synthesis by macrophages is significant by the Kruskal-Wallace one-way ANOVA, ${ }^{*} P<0.05$. In addition, the difference in $\mathrm{PGE}_{2}$ formation by monocytes and macrophages is significant by two-way ANOVA, ${ }^{* *} P$ $<0.025$.
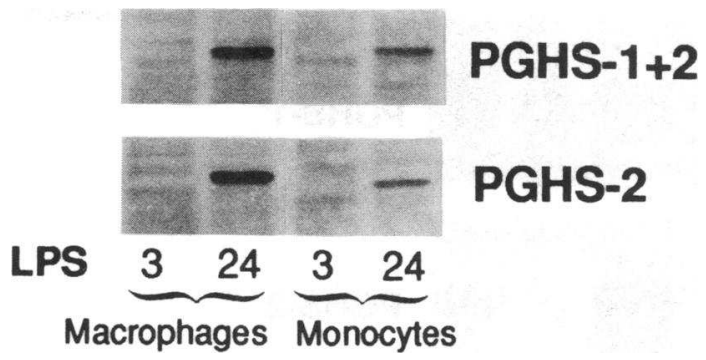

Figure 4. Detection of PGHS-2 in monocytes and macrophages. Macrophages and monocytes were cultured 3 or $24 \mathrm{~h}$ in the presence of $10 \mu \mathrm{g} / \mathrm{ml}$ LPS. Cell proteins were then immunoblotted with the in-house antibody (PGHS-1 + 2) or the antibody specific for PGHS-2 (PGHS-2).

in-house antibody (antibody $A$ ). Fig. 5 demonstrates that the anti-PGHS-2 antibody detects only PGHS-2. These findings support the hypothesis that the new protein is PGHS-2.

Based on the observations of other investigators $(5,6,7$, 18 ), it seemed likely that appearance of PGHS-2 protein would require an increase in PGHS-2 mRNA. To explore this question, Northern blotting of human macrophage and monocyte RNA was performed following incubation with human cDNA probes for PGHS-1 and PGHS-2. These studies, shown in Fig. 6 , demonstrate that the PGHS-2 cDNA probe detects an approximately $5-\mathrm{kb}$ message in macrophages and, to a lesser degree, in monocytes exposed to LPS (7). The message detected by the PGHS-1 cDNA, also $\sim 5 \mathrm{~kb}$, did not change (7). These findings show that LPS causes an increase in PGHS-2 message in human macrophages and monocytes. In addition, the findings strengthen our hypothesis that the new protein is PGHS-2.

We speculated that the increase in PGHS-2 mass induced by LPS resulted in the increase in $\mathrm{PGE}_{2}$ synthesis. However, if PGHS-2 were an inactive protein, prostaglandin synthesis might still increase if LPS caused higher phospholipase $\mathrm{A}_{2}$ activity, making more substrate available for PGHS-1 $(11,19,20$, 21 ). To explore this possibility, $24 \mathrm{~h}$ of LPS stimulated macrophages and monocytes were washed with buffer and then exposed to $20 \mu \mathrm{M}$ arachidonic acid for $15 \mathrm{~min}$. If the newly synthesized PGHS-2 were active, then the LPS-exposed cells would make more $\mathrm{PGE}_{2}$ than controls when stimulated with extracellular arachidonic acid. Fig. 7 demonstrates that control cells make little $\mathrm{PGE}_{2}$ in the basal state (graph $A$ ) and undetect-

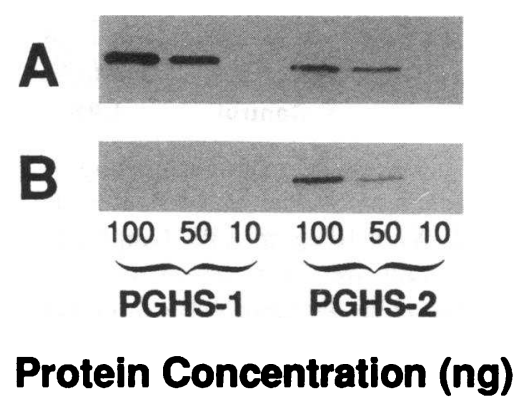

Figure 5. Sensitivity and specificity of antibodies to PGHS-1 and PGHS2 protein. Our in-house antibody $(A)$, and an antibody specific for PGHS-2 $(B)$, were immunoblotted against purified ram seminal vesicle PGHS-1 (70 kD) and a recombinant chicken PGHS-2 (69 kD). Antibody A was diluted 1:5,000. Antibody B was diluted 1:200. The quantity, in nanograms, of PGHS-1 and PGHS-2 protein is shown at the bottom of the figure. Note that the recombinant chicken PGHS-2, shown above, has a lower molecular weight than the human protein. 


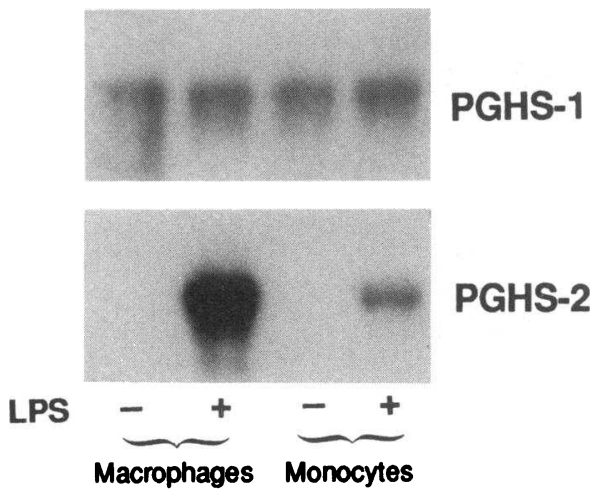

Figure 6. Effect of LPS on PGHS-1 and PGHS-2 mRNA. Macrophages and monocytes were cultured $24 \mathrm{~h}$ in the absence $(-)$ or presence (+) of $10 \mu \mathrm{g} / \mathrm{ml}$ LPS. Northern analysis was then performed using ${ }^{32} \mathrm{P}$-labeled human cDNA probes specific for PGHS-1 mRNA (PGHS-1) and PGHS-2 mRNA (PGHS-2).

able amounts when exposed to arachidonic acid (graph $B$ ). This demonstrates that cells not exposed to LPS have limited ability to generate $\mathrm{PGE}_{2}$, indicating that the constitutive enzyme, PGHS-1, has low activity. However, the LPS-exposed cells generate $\mathrm{PGE}_{2}$ in the 24-h culture medium ( graph $A$ ) and immediately synthesize $\mathrm{PGE}_{2}$ when exogenous arachidonic acid is added ( graph $B$ ). In both cases the macrophages generate more $\mathrm{PGE}_{2}$ than the monocytes. These results support the conclusion that PGHS- 2 is the primary cyclooxygenase in macrophages and monocytes after LPS stimulation. In addition, these observations indicate that synthesis of PGHS- 2 is required for macrophages and monocytes to increase their capacity to generate $\mathrm{PGE}_{2}$ from arachidonic acid.
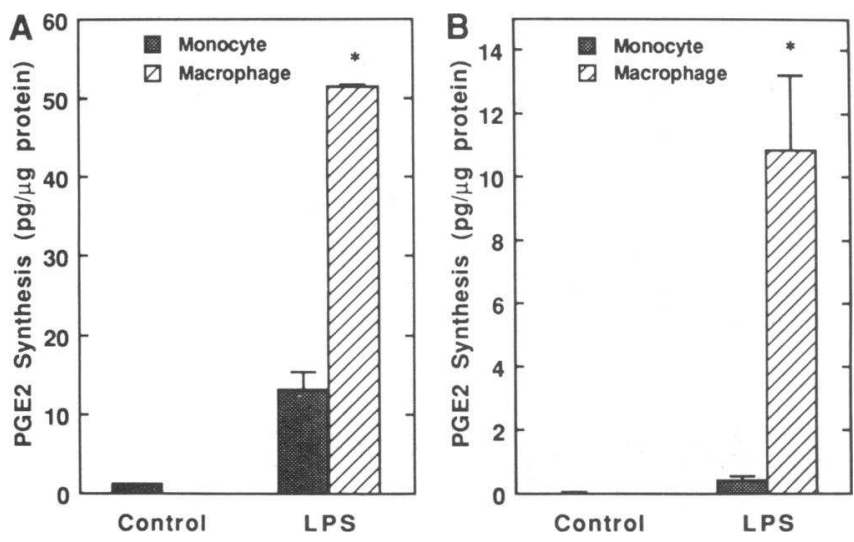

Figure 7. Effect of LPS on $\mathrm{PGE}_{2}$ synthesis by macrophages and monocytes. Macrophages and monocytes were cultured $24 \mathrm{~h}$ in the absence (Control) or presence ( $L P S$ ) of $10 \mu \mathrm{g} / \mathrm{ml}$ LPS. Graph $(A)$ shows $\mathrm{PGE}_{2}$ released into the medium over $24 \mathrm{~h}$. Error bars are $\pm \mathrm{SEM}, n=3$. The difference in $\mathrm{PGE}_{2}$ synthesis between monocytes and macrophages exposed to LPS was statistically significant, ${ }^{*} P<0.0005$ by the unpaired $t$ statistic. Graph $(B)$ shows $\mathrm{PGE}_{2}$ synthesized after the cells used in graph $A$ were washed and then stimulated with $20 \mu \mathrm{M}$ arachidonic acid for $15 \mathrm{~min}$. The difference in $\mathrm{PGE}_{2}$ formation between LPS-exposed monocytes and macrophages stimulated with arachidonic acid was statistically significant, ${ }^{*} P<0.002$ by the unpaired $t$ statistic. Note that the magnitude of the $y$-axis is smaller in graph $B$.

\section{Discussion}

These studies demonstrate that LPS stimulates production of large amounts of PGHS-2 in human alveolar macrophages and smaller amounts of this protein in peripheral blood monocytes. The increase in PGHS-2 mass is associated with increased formation of $\mathrm{PGE}_{2}$. The constitutive cyclooxygenase, PGHS-1, appears to have very low activity. This implies that both of these cell types require synthesis of PGHS-2 before they are able to generate larger amounts of $\operatorname{PGE}_{2}(10,22)$. However, the human alveolar macrophage has greater capacity to synthesize $\mathrm{PGE}_{2}$, demonstrating an important difference between the resident airway macrophage and the peripheral blood monocyte.

The observation that PGHS-1 does not generate prostaglandin after exposure to exogenous arachidonic acid as shown in Fig. 7, does not prove that the constitutive enzyme is structurally inactive. It may be that PGHS-1 has been previously inactivated by generating prostaglandin from endogenous arachidonic acid (23). In that case, new enzyme synthesis would be required for PGHS-1 to demonstrate activity. If the turn-over of PGHS- 1 in alveolar macrophages is slow, then at any one time there would be very little active enzyme in the cell. This seems the most likely explanation for the apparent inactivity of the enzyme demonstrated in Fig. 7, since the results in Fig. $2\left(\right.$ Panel $B$ ) indicate a small basal level of $\mathrm{PGE}_{2}$ generation.

In support of this interpretation, PGHS- 1 is active in other cells $(24,25)$. Human umbilical vein endothelium, for example, produces large amounts of prostaglandin in response to thrombin or exogenous arachidonic acid, but contains almost exclusively PGHS-1 (our unpublished observations). This tissue has slow turnover of functional enzyme. Following inactivation of endothelial PGHS-1 with excess arachidonic acid, $\mathrm{H}_{2} \mathrm{O}_{2}$, reoxygenation, or aspirin, 6 to $48 \mathrm{~h}$ is required for return of $\mathrm{PGI}_{2}$ synthesis, even though prostacyclin synthase remains active $(26,27,28,29,30)$, implying a slow turnover of PGHS1. These functional observations differ from the much faster turnover rates calculated by pulse-chase methods $(31,32)$.

The peripheral blood monocyte, believed to be the primary source of human alveolar macrophages, migrates from the blood compartment to become a resident of the lung airspace $(33,34,35)$. During this process the cell increases in size, acquires increased phagocytic, tumoricidal, and microbicidal abilities, and becomes able to synthesize lipoxygenase products $(36,37,38,39,40)$. In addition, as demonstrated by the experiments in this study, the cell also acquires an increased capacity to synthesize the protein PGHS-2 and its product PGE $_{2}$.

The acquired ability of the macrophage to synthesize more $\mathrm{PGE}_{2}$ than the blood monocyte may be protective of the human lung. $\mathrm{PGE}_{2}$ has been demonstrated to inhibit IL-1 activity, PMA-induced lymphocyte proliferation, IL- 8 synthesis, and synthesis of collagen by fibroblasts $(1,41,42)$. It is also an effective bronchodilator. Alternatively, the lower capacity of the peripheral blood monocyte to generate $\mathrm{PGE}_{2}$ may also have protective benefits to the host. For example, in the blood compartment inhibiting lymphocyte proliferation, neutrophil migration (an IL-8 function), and collagen synthesis may decrease the host's ability to control infection. In that case, less $\mathrm{PGE}_{2}$ would be beneficial.

The discovery of PGHS-2 has greatly advanced our understanding of prostaglandin regulation. Previous observations of 
increased $\mathrm{PGE}_{2}$ synthesis after exposure of cells to v-src, IL-1, IL-2, TNF, PDGF, phorbol esters, cAMP, and LPS can now be explained by the ability of these agents to induce synthesis of PGHS-2 $(4,7,20,22,43-47)$. The only known tissues, at the time of this writing, in which PGHS-2 mRNA is expressed primarily are prostate and neonatal thymus (48). In tissues in which PGHS-2 is expressed in response to an exogenous signal, such as LPS, it has characteristics of an early response gene (49).

In this study we demonstrate that human monocytes and macrophages have no detectable message for PGHS-2 under control conditions. After LPS there is appearance of an easily detectable $\sim 5-\mathrm{kb}$ mRNA that binds the PGHS-2 cDNA probe. The amount of message is greater in macrophages, consistent with the findings of increased PGHS-2 protein and $\mathrm{PGE}_{2}$ synthesis by these cells. These observations are similar to reports on other species and tissues, which demonstrate a single $\sim 4$.5-kb mRNA binding PGHS-2 cDNA after LPS or mitogen exposure $(5,6,7,47,50,51)$. Our results differ from these reports in that we do not find a $\sim 2.8$-kb message for PGHS- 1 . However, we do detect a message of $\sim 5 \mathrm{~kb}$ that binds the PGHS-1 cDNA probe. This larger message has been detected in other reports $(7,47,50,52)$ and is prominent in human tissues $(7,40,52)$.

To confirm that our probe would detect the $2.8-\mathrm{kb}$ message, we probed human dermal fibroblasts and detected both the 2.8- and the 5-kb messages. We then superinduced PGHS-2 with IL-1 and cycloheximide. The PGHS-2 probe detected a new 5-kb mRNA but the PGHS-1 2.8- and 5-kb bands did not change. These findings demonstrate that the PGHS-1 probe detects the 2.8-kb message and does not cross react with the PGHS-2 mRNA. At this time, we are unable to explain the absence of the $2.8-\mathrm{kb}$ message in our cells.

The observations in this manuscript demonstrate the necessity of PGHS-2 for increasing synthesis of $\mathrm{PGE}_{2}$ by the human alveolar macrophage and the peripheral blood monocyte. The observations we report are consistent with findings in rabbits and rats, which indicate that increased PGHS-2 mass correlates with increased $\mathrm{PGE}_{2}$ synthesis in alveolar macrophages after LPS stimulation $(6,10)$. Our findings are in contrast to a primary role for PGHS-1 in macrophage prostaglandin synthesis, as suggested by recent studies on rat peritoneal and alveolar macrophages (11).

In summary, these observations demonstrate that, in humans, it is the inducible cyclooxygenase, PGHS-2, and not the constitutive enzyme, PGHS-1, that increases the capacity of the alveolar macrophage and the blood monocyte to generate prostaglandins after exposure to LPS.

\section{Acknowledgments}

This work was supported by an American Heart Association-Genentech Clinician-Scientist Award, by a Department of Veterans Affairs Merit Review Award, and by a National Heart, Lung and Blood Institute (NHLBI) grant HL-02608 to Dr. Hempel; and by a Department of Veterans Affairs Merit Review Award and a NHLBI Specialized Center for Research grant HL-37121 to Dr. Hunninghake; and by a National Institutes of Health Clinical Research Center grant RR-59 to The University of Iowa, College of Medicine.

\section{References}

1. Monick, M., J. Glazier, and G. W. Hunninghake. 1987. Human alveolar macrophages suppress interleukin-1 (IL-1) activity via the secretion of prostaglandin $\mathrm{E}_{2}$. Am. Rev. Respir. Dis. 135:72-77.
2. Brown, G. P., M. M. Monick, and G. W. Hunninghake. 1988. Human alveolar macrophage arachidonic acid metabolism. Am. J. Physiol. (Cell Physiol. 23). 254:C809-C815.

3. Pueringer, R. J., and G. W. Hunninghake. 1992. Lipopolysaccharide stimulates de novo synthesis of PGH synthase in human alveolar macrophages. Am. J. Physiol. (Lung Cell. Mol. Physiol. 6). 262:L78-L85.

4. Rosen, G. D., T. M. Birkenmeier, A. Raz, and M. J. Holtzman. 1989. Identification of a cyclooxygenase-related gene and its potential role in prostaglandin formation. Biochem. Biophys. Res. Comm. 164:1358-1365.

5. Kujubu, D. A., B. S. Fletcher, B. C. Varnum, R. W. Lim, and H. R Herschman. 1991. TIS10, a phorbol ester tumor promoter-inducible mRNA from Swiss 3T3 cells, encodes a novel prostaglandin synthase/cyclooxygenase homologue. J. Biol. Chem. 266:12866-12872.

6. O'Sullivan, M. G., F. H. Chilton, E. M. Huggins, Jr., and C. E. McCall. 1992. Lipopolysaccharide priming of alveolar macrophages for enhanced synthesis of prostanoids involves induction of a novel prostaglandin $\mathrm{H}$ synthase. J. Biol. Chem. 267:14547-14550.

7. Hla, T., and K. Neilson. 1992. Human cyclooxygenase-2 cDNA. Proc. Natl. Acad. Sci. USA. 89:7384-7388.

8. O’Sullivan, M. G., E. M. Huggins, Jr., E. A. Meade, D. L. DeWitt, and C. E. McCall. 1992. Lipopolysaccharide induces prostaglandin $\mathrm{H}$ synthase- 2 in alveolar macrophages. Biochem. Biophys. Res. Comm. 187:1123-1127.

9. Holtzman, M. J., J. Turk, and L. P. Shornick. 1992. Identification of a pharmacologically distinct prostaglandin $\mathrm{H}$ synthase in cultured epithelial cells. J. Biol. Chem. 267:21438-21445.

10. Lee, S. H., E. Soyoola, P. Chanmugam, S. Hart, W. Sun, H. Zhong, S. Liou, D. Simmons, and D. Hwang. 1992. Selective expression of mitogen-inducible cyclooxygenase in macrophages stimulated with lipopolysaccharide. J. Biol. Chem. 267:25934-25938.

11. Wilborn, J., and M. Peters-Golden. 1992. Differential expression of two distinct cyclooxygenase gene products in rat alveolar and peritoneal macrophages. Clin. Res. 40:722A. (Abstr.)

12. Iwamoto, G. J., M. M. Monick, L. F. Burmeister, and G. W. Hunninghake. 1989. Interleukin 1 release by human alveolar macrophages and blood monocytes. Am. J. Physiol. (Cell Physiol. 25). 256:C1012-C1015.

13. Zavala, D. C., and G. W. Hunninghake. 1983. Lung Lavage. In Recent Advances in Respiratory Medicine. D. C. Glenley and T. L. Petty, editors. Churchill Livingston, Edinburgh, UK. 21-33.

14. Boyum, A. 1968. Isolation of mononuclear cells and granulocytes from human blood. J. Clin. Lab. Invest. 21:77-89.

15. Bradford, M. M. 1976. A rapid and sensitive method for the quantitation of microgram quantities of protein utilizing the principle of protein-dye binding. Anal. Biochem. 72:248-254.

16. Stinski, M. F., D. R. Thomsen, R. M. Stenberg, and L. C. Goldstein. 1983. Organization and expression of the immediate early genes of human cytomegalovirus. J. Virol. 46:1-14.

17. Lehrach, D., D. Diamond, J. M. Wozney, and H. Boedtkes. 1977. RNA molecular weight determinations by gel electrophoresis under denaturing conditions, a critical reexamination. Biochemistry. 16:4743-4751.

18. Fu, J. Y., J. L. Masferrer, K. Seibert, A. Raz, and P. Needleman. 1990. The induction and suppression of prostaglandin $\mathrm{H}_{2}$ synthase (cyclooxygenase) in human monocytes. J. Biol. Chem. 265:16737-16740.

19. Aderem, A. A., D. S. Cohen, S. D. Wright, and Z. A. Cohn. 1986. Bacterial lipopolysaccharides prime macrophages for enhanced release of arachidonic acid metabolites. J. Exp. Med. 164:165-179.

20. Lin, A. H., M. J. Bienkowski, and R. R. Gorman. 1989. Regulation of prostaglandin $\mathrm{H}$ synthase $\mathrm{mRNA}$ levels and prostaglandin biosynthesis by platelet-derived growth factor. J. Biol. Chem. 264:17379-17383.

21. Murakami, M., I. Kodo, and K. Inoue. 1993. Molecular nature of phospholipases $A_{2}$ involved in prostaglandin $I_{2}$ synthesis in human umbilical vein endothelial cells. J. Biol. Chem. 268:839-844.

22. Nusing, R., and V. Ullrich. 1992. Regulation of cyclooxygenase and thromboxane synthase in human monocytes. Eur. J. Biochem. 206:131-136.

23. Hemler, M. E., and W. E. M. Lands. 1980. Evidence for a peroxide-initiated free radical mechanism of prostaglandin biosynthesis. J. Biol. Chem. 255:6253-6261.

24. Shimokawa, T., and W. L. Smith. 1992. Prostaglandin endoperoxide synthase: The aspirin acetylation region. J. Biol. Chem. 267:12387-12392.

25. Smith, W. L. 1992. Prostanoid biosynthesis and mechanisms of action. Am. J. Physiol. (Renal Fluid Electrolyte Physiol. 32). 263:F181-F191.

26. Adams-Brotherton, A. F., and J. C. Hoak. 1983. Prostacyclin biosynthesis in cultured vascular endothelium is limited by deactivation of cyclooxygenase. $J$. Clin. Invest. 72:1255-1261.

27. Willems, C., P. G. de Groot, G. A. Pool, M. S. Gonsalvez, W. G. Van Aken, and J. A. Van Mourik. 1982. Arachidonate metabolism in cultured human vascular endothelial cells evidence for two prostaglandin synthetic pathways sensitive to acetylsalicylcic acid. Biochem. Biophys. Acta. 713:581-588.

28. Hempel, S. L., D. L. Haycraft, J. C. Hoak, and A. A. Spector. 1990. Reduced prostacyclin formation after reoxygenation of anoxic endothelium. Am. J. Physiol. (Cell Physiol. 28). 259:C738-C745. 
29. Barchowsky, A., R. S. Kent, and A. R. Whorton. 1987. Recovery of porcine aortic endothelial cell prostaglandin synthesis following inhibition by sublethal concentrations of hydrogen peroxide. Biochim. Biophys. Acta. 927:372-381.

30. Jaffe, E. A., R. L. Nachman, C. G. Becker, and C. R. Minick 1973. Culture of human endothelial cells derived from umbilical veins. J. Clin. Invest 52:2745-2756.

31. Wu, K. K., H. Hatzakis, S. S. Lo, D. C. Seong, and S. K. Sanduja. 1988 Stimulation of de novo synthesis of prostaglandin $\mathrm{G} / \mathrm{H}$ synthase in human endothelial cells by phorbol ester. J. Biol. Chem. 263:19043-19047.

32. Tsai, A. L., R. Sanduja, and K. K. Wu. 1990. Evidence for two pools of prostaglandin $\mathrm{H}$ synthase in human endothelial cells. In Advances in Prostaglandin, Thromboxane, and Leukotriene Research, Vol 19. B. Samuelsson, P. Y.-K Wong, and F. F. Sun, editors. Raven Press Ltd., New York. 454-457.

33. Bowden, D. H., and I. Y. R. Adamson. 1980. Role of monocytes and interstitial cells in the generation of alveolar macrophages, I. Lab. Invest. 42:511 517.

34. Adamson, I. Y. R., and D. H. Bowden. 1980. Role of monocytes and interstitial cells in the generation of alveolar macrophages, II. Lab. Invest. 42:518-524.

35. Thomas, E. D., R. E. Ramberg, and G. E. Sale. 1976. Direct evidence for a bone marrow origin of the alveolar macrophage in man. Science (Wash. DC) 192:1016-1018.

36. Rinehart, J. J., A. Wuest, and G. A. Ackerman. 1982. Corticosteroid alteration of human monocyte to macrophage differentiation. J. Immunol. 129:1436-1440.

37. Newman, S. L., J. E. Henson, and P. M. Henson. 1982. Phagocytosis of senescent neutrophils by human monocyte-derived macrophages and rabbit inflammatory macrophages. J. Exp. Med. 156:430-442.

38. Stevenson, H. C., P. Katz, D. G. Wright, T. J. Contreras, J. F. Jemioneky, V. M. Hartwig, W. J. Fler, and A. S. Fauci. 1981. Human blood monocytes: characterization of negatively selected human monocytes and their suspension cell culture derivatives. Scand. J. Immunol. 14:243-256.

39. Kemmerich, B., R. H. Rossing, and J. E. Pennington. 1987. Comparative oxidative microbicidal activity of human blood monocytes and alveolar macrophages and activation by gamma interferon. Am. Rev. Respir. Dis. 136:266-270.

40. Bigby, T. D., and M. J. Holtzman. 1987. Enhanced 5-lipoxygenase activity in lung macrophages compared to monocytes from normal subjects. $J$. Im munol. 138:1546-1550.

41. Standiford, T. J., S. L. Kunkel, M. W. Rolfe, H. L. Evanoff, R. M. Allen, and R. M. Strieter. 1992. Regulation of human alveolar macrophage- and blood monocyte-derived interleukin-8 by prostaglandin $\mathrm{E}_{2}$ and dexamethasone. Am. J. Respir. Cell Mol. Biol. 6:75-81.

42. Rennard, S. I., J. Moss, J. Oberpriller, B. Horn, L. Stier, T. Ozaki, and R. G. Crystal. 1983. Fibroblasts: important producers and targets of inflammatory prostaglandins in the lungs. Chest. 83(5):92S-93S.

43. Bachwich, P. R., S. W. Chensue, J. W. Larrick, and S. L. Kunkel. 1986. Tumor necrosis factor stimulates interleukin-1 and prostaglandin $\mathrm{E}_{2}$ production in resting macrophages. Biochem. Biophys. Res. Comm. 136:94-101.

44. Goerig, M., A. J. R. Habenicht, W. Zeh, P. Salbach, B. Kommerell, D. E. R. Rothe, W. Nastainczyk, and J. A. Glomset. 1988. Evidence for coordinate, selective regulation of eicosanoid synthesis in platelet-derived growth factorstimulated 3T3 fibroblasts and in HL-60 cells induced to differentiate into macrophages or neutrophils. J. Biol. Chem. 263:19384-19391.

45. Balter, M., G. Toews, and M. Peters-Golden. 1989. Different patterns of arachidonate metabolism in autologous human blood monocytes and alveolar macrophages. J. Immunol. 142:602-608.

46. Han, J. W., H. Sadowski, D. A. Young, and I. G. Macara. 1990. Persistent induction of cyclooxygenase in $6^{\mathrm{v}-\mathrm{sr}}$-transformed 3T3 fibroblasts. Proc. Natl. Acad. Sci. USA. 87:3373-3377.

47. Diaz, A., A. M. Reginato, and S. A. Jimenez. 1992. Alternative splicing of human prostaglandin $G / H$ synthase $m R N A$ and evidence of differential regulation of the resulting transcripts by transforming growth factor $\beta_{1}$, interleukin $1 \beta$, and tumor necrosis factor $\alpha$. J. Biol. Chem. 267:10816-10822.

48. Xie, W., D. L. Robertson, and D. L. Simmons. 1992. Mitogen-inducible prostaglandin G/H synthase: A new target for nonsteroidal antiinflammatory drugs. Drug Devel. Res. 25:249-265.

49. Maier, J. A. M., T. Hla, and T. Maciag. 1990. Cyclooxygenase is an immediate-early gene induced by interleukin-1 in human endothelial cells. $J$. Biol. Chem. 265:10805-10808.

50. Xie, W., J. G. Chipman, D. L. Robertson, R. L. Erikson, and D. L. Simmons. 1991. Expression of a mitogen-responsive gene encoding prostaglandin synthase is regulated by mRNA splicing. Proc. Natl. Acad. Sci. USA. 88:2692-2696.

51. O'Bannion, M. K., V. D. Winn, and D. A. Young. 1992. cDNA cloning and functional activity of a glucocorticoid-regulated inflammatory cyclooxygenase. Proc. Natl. Acad. Sci. USA. 89:4888-4892.

52. DeWitt, D. L., E. A. El-Harith, and W. L. Smith. 1989. Molecular cloning of prostaglandin G/H synthase. In Advances in Prostaglandin, Thromboxane and Leukotriene Research, Vol. 19. B. Samuelsson, P. Y.-K. Wong, and F. F. Sun, editors. Raven Press Ltd., New York. 454-457. 